\title{
Elimination of Methylene Blue and Reactive Black 5 from Aqueous Solution Using HKUST-1
}

\author{
S. Loera-Serna, H. Solis, E. Ortiz, A. L. Martínez-Hernandéz, and L. Noreña
}

\begin{abstract}
The HKUST-1 copper metal organic framework (MOF) is one of the most studied MOFs because it has high pore volume, a large surface area, high chemical stability and also the ability to bind water, among other molecules, by coordinating to the unsaturated $\mathrm{Cu}(\mathrm{II})$ sites. In this study we propose two strategies for the elimination of two dyes from aqueous solution employing HKUST-1: methylene blue, MB, (with a initial concentration of $200 \mathrm{ppm}$ ) and reactive black 5, RB5, (with a initial concentration of $100 \mathrm{ppm}$ ). The first strategy involves in-situ (IS) adsorption where MB or RB5 are added to the HKIST-1 synthesis precursors and the porous structure is formed including MB or RB5 molecules. The second strategy corresponds to post-synthesis (PS) elimination. HKUST-1 is obtained by stirring at room temperature and pretreated at $100{ }^{\circ} \mathrm{C}$ during $12 \mathrm{~h}$. Finally, MB or RB5 was incorporated into the HKUST-1 structure by contact solution. MOFs were characterized by XDR, FTIR, TGA and UV-Vis, in order to compare both methods and for identifying the physicochemical properties of the obtained materials. XRD results corroborate that all synthesized materials correspond to the cubic HKUST-1 structure, with different reticular parameters. The UV-Vis results show that the IS adsorption of MB and RB5 in HKUST-1, produced a guest loading of $58.11 \%$ and $82.68 \%$, respectively. Whereas, the PS method reached a dye loading of $93.57 \%$ and $75.01 \%$ for $\mathrm{MB}$ and RB5, respectively.
\end{abstract}

Index Terms-HKUST-1, MOF, methylene blue, reactive black 5, adsorption.

\section{INTRODUCTION}

Dyes are used in many industries such as in textiles, plastics, food, cosmetics, carpets, paper, pharmaceuticals, among others [1]. The contamination of water by these dyes generates important environmental problems, due to the incomplete and slow degradation of the dyes. Some degradation processes eliminate the color of wastewater but some times generate more toxic products than the initial dyes [2], [3]. For this reason, porous materials are good candidates for eliminating dyes from wastewater. Dye adsorption using porous materials is by far the most simple and effective technique owing to advantages of being a fast adsorption, high absorbent capacities, weak interaction with dye

Manuscript received September 9, 2016; revised November 14, 2016 This work was supported by the CONACyT under projects 154736 and 153663.

S. Loera-Serna, H. Solis, E. Ortiz, and L. Noreña are with the Metropolitan Autonomous University, Azcapotzalco, Av. San Pablo 180, Col. Reynosa Tamaulipas, Azcapotzalco, Ciudad de México, 02200, Mexico (e-mail: sls@correo.azc.uam.mx).

A. L. Martínez-Hernandéz is with Research Division at Instituto Tecnologico de Querétaro (Queretaro Technological Institute). Av. Tecnológico s/n, Centro, Santiago de Querétaro, 76000, QRO, Mexico. molecules, easy regeneration, the possibility of desorbing dye molecules and the low-cost of porous materials. Also, the adsorbent can be designed with specific physicochemical properties such as: well defined pore size, high surface area, high thermal stability, low-cost synthesis, nanometric particle size, among others [4]-[6].

Methylene blue (MB) and reactive black 5 (RB5) are the typical dyes (Fig. 1), and have been widely used in textile, food, cosmetic, pharmaceutical industries. $\mathrm{MB}$ is also employed in aquariums due to its antifungal properties [7]-[9]. These dyes have been previously adsorbed in porous materials such as: kaolinite, activated charcoal and MOF, among others. Table I summarizes the principal adsorbents used, the maximum retention percentage and the adsorption conditions [10]-[22].
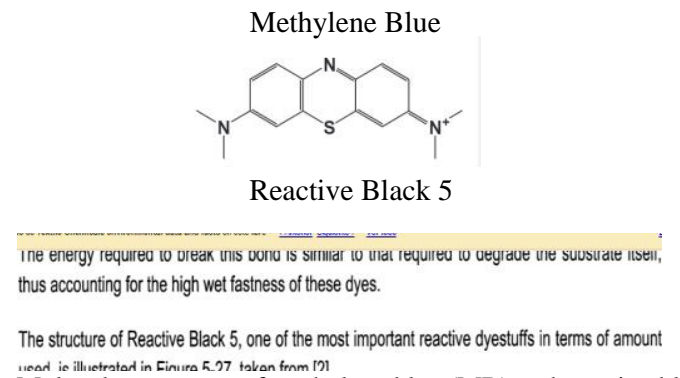

The structure of Reactive Black 5 , one of the most important reactive dyestuffs in terms of amoun

Fig. 1. Molecular structure of methylene blue (MB) and reactive black 5 (RB5).

The advanced and expensive water treatment technology cannot eliminate completely all dyes present in wastewater [3]. A recent invention of crystalline materials, formed by organic ligands and a metal center, has generated interest because of their various applications including drug retention, catalysis, guest adsorption (molecular recognition), optical applications, sensor technologies, dyes adsorption and gas storage [23]-[28]. These materials are metal organic frameworks (MOFs), they have the ability to store compounds in its porous structure or on their surface, due to the 3D structure. Both, the metal centers and the organic ligands, can be chosen depending on the field of application.

The main structural feature of HKUST-1 is a monomeric unit containing a dicopper cluster with a copper-copper distance of $2.63 \mathrm{~A}$. The space group of HKUST-1 is a face centered crystal lattice with Fm-3m symmetry which possesses a 3D channel system with a bimodal pore size distribution, a cell parameter and cell volume of $26.34 \mathrm{~A}$ and $18.28 \mathrm{~A}^{3}$, respectively [29]. Ever since the synthesis of HKUST-1 was reported by Chui, et al. [29] this material has been synthesized many times [30], [31]. The HKUST-1 we employed in the present study is different to others since our synthesis method is carried out stirring at room temperature, by the one-pot metathesis method [31]. A few articles about 
dyes adsorption on HKUST-1 are already reported, adsorption on HKUST-1 have been reported [12]-[14]. nevertheless, to our knowledge, no papers about RB5

TABLE I: ADSORBENTS OF MB AND RB5: MAXIMUM AMOUNT AND CONDITIONS

\begin{tabular}{|c|c|c|c|c|}
\hline Dye & Adsorbent & Adsorption conditions & Maximum retention percentage & Reference \\
\hline \multirow[t]{19}{*}{ MB } & \multirow[t]{3}{*}{ HKUST-1 } & $C_{0}=1.0 \mu \mathrm{mol} \cdot \mathrm{L}^{-1}$ to 10 & $15.28 \mu \mathrm{mol} \cdot \mathrm{g}^{-1}(298 \mathrm{~K})$ & \multirow[t]{3}{*}[12]{} \\
\hline & & $\mu \mathrm{mol} \cdot \mathrm{L}^{-1}, \mathrm{~T}=298,308$ and 318 & $11.79 \mu \mathrm{mol} \cdot \mathrm{g}^{-1}(308 \mathrm{~K})$ & \\
\hline & & K. & $11.10 \mu \mathrm{mol} \cdot \mathrm{g}^{-1}(318 \mathrm{~K})$ & \\
\hline & \multirow[t]{3}{*}{ MOF-235 } & $5 \mathrm{mg}$ of $\mathrm{MOF}$ & $187 \mathrm{mg} \cdot \mathrm{g}^{-1}(298 \mathrm{~K})$ & \multirow[t]{3}{*}[13]{} \\
\hline & & $C_{0}=100 \mathrm{ppm}$ & $230 \mathrm{mg} \cdot \mathrm{g}^{-1}(308 \mathrm{~K})$ & \\
\hline & & $\mathrm{T}=298,308$ and $318 \mathrm{~K}$ & $252 \mathrm{mg} \cdot \mathrm{g}^{-1}(318 \mathrm{~K})$ & \\
\hline & \multirow[t]{2}{*}{ MIL-68 (Al) } & \multirow[t]{2}{*}{$C_{0}=0.3$ to $5 \mathrm{mg} \cdot \mathrm{L}^{-1}$} & $67 \mathrm{mg} \cdot \mathrm{g}^{-1} \quad(\mathrm{pH}=7.96)$ & \multirow[t]{2}{*}[14]{} \\
\hline & & & $60 \mathrm{mg} \cdot \mathrm{g}^{-1}(\mathrm{pH}=6.50)$ & \\
\hline & \multirow{5}{*}{$\begin{array}{l}\text { cotton stalk (CS) } \\
\text { sulphuric acid treated CS } \\
\text { (SCS) } \\
\text { phosphoric acid treated CS } \\
\text { (PCS) } \\
\text { hazelnut shell }\end{array}$} & \multirow{3}{*}{$\begin{array}{l}\mathrm{T}=308 \pm 2 \mathrm{~K} \\
\mathrm{t}=120 \mathrm{~min}\end{array}$} & $25.65 \mathrm{mg} \cdot \mathrm{g}^{-1}\left(\mathrm{C}_{0}=825 \mathrm{mg} \cdot \mathrm{L}^{-1}\right.$ of $\left.\mathrm{CS}\right)$ & \multirow[t]{3}{*}[15]{} \\
\hline & & & $\begin{array}{l}646.12 \mathrm{mg} \cdot \mathrm{g}^{-1}\left(\mathrm{C}_{0}=1415 \mathrm{mg} \cdot \mathrm{L}^{-1} \text { of } \mathrm{SCS}\right), \\
105.38 \mathrm{mg} \cdot \mathrm{g}^{-1}\left(\mathrm{C}_{0}=1415 \mathrm{mg} \cdot \mathrm{L}^{-1} \text { of PSC }\right)\end{array}$ & \\
\hline & & & & \\
\hline & & $\mathrm{pH}=4.1-4.5, \mathrm{SS}=200 \mathrm{rpm}$ & ca. $15 \mathrm{~mol} \cdot \mathrm{g}^{-1}$ & [16] \\
\hline & & $\begin{array}{l}\mathrm{PS}=0-75 \mu \mathrm{m}, C_{0}=1 \times 10^{-4} \\
\mathrm{~mol} \cdot \mathrm{L}^{-1}, \mathrm{t}=40 \mathrm{~min}, \mathrm{~T}=303 \mathrm{~K}\end{array}$ & & \\
\hline & USM-chitin & $\begin{array}{l}\mathrm{C}_{0}=\text { of } 50 \mathrm{mg} \mathrm{L}^{-1}, \mathrm{~T}=298 \mathrm{~K} \\
\mathrm{SS}=150 \mathrm{rpm}, \mathrm{t}=6 \mathrm{~h}\end{array}$ & $26.69 \mathrm{mg} \cdot \mathrm{g}^{-1}$ & {$[17]$} \\
\hline & garlic peel & $\begin{array}{l}\mathrm{C}_{0}=25-200 \mathrm{mg} \cdot \mathrm{L}^{-1}, \mathrm{pH}=4-12, \\
\mathrm{~T}=303,313 \text { and } 323 \mathrm{~K}\end{array}$ & $\begin{array}{l}82.64 \mathrm{mg} \cdot \mathrm{g}^{-1}(303 \mathrm{~K}), 123.45 \mathrm{mg} \cdot \mathrm{g}^{-1}(313 \\
\mathrm{K}) \text {, and } 142.86 \mathrm{mg} \cdot \mathrm{g}^{-1}(323 \mathrm{~K})\end{array}$ & [18] \\
\hline & \multirow{2}{*}{$\begin{array}{l}\text { bamboo-based activated } \\
\text { carbon }\end{array}$} & $\mathrm{T}=303 \mathrm{~K}$ & $454.2 \mathrm{mg} / \mathrm{g}$ & \multirow[t]{2}{*}{ [19] } \\
\hline & & \multicolumn{2}{|l|}{$0.2 \mathrm{~g}, \mathrm{PS}=150 \mu \mathrm{m}, \mathrm{t}=48 \mathrm{~h}$} & \\
\hline & Graphene & $\mathrm{C}_{0}=1000 \mathrm{mg} \cdot \mathrm{L}^{-1}, \mathrm{~T}=293 \mathrm{~K}$ & $153.85 \mathrm{mg} \cdot \mathrm{g}^{-1}$ & {$[20]$} \\
\hline & $\begin{array}{l}\text { humic acid-coated } \mathrm{Fe}_{3} \mathrm{O}_{4} \\
\text { nanoparticle }\end{array}$ & $\begin{array}{l}\mathrm{C}_{0}=1 \mathrm{mg} \cdot \mathrm{L}^{-1}, \mathrm{~T}=298 \mathrm{~K} \\
\mathrm{~T}=7 \mathrm{~min}\end{array}$ & $0.291 \mathrm{mmol} \cdot \mathrm{g}^{-1}$ & {$[22]$} \\
\hline RB5 & $\begin{array}{l}\text { Activated carbon (PAC) } \\
\text { Afsin-Elbistan fly ash (AE) }\end{array}$ & $\mathrm{C}_{0}=50 \mathrm{mg} / \mathrm{L}, \mathrm{SS}=200 \mathrm{rpm}$ & $\begin{array}{l}58.823 \mathrm{mg} \cdot \mathrm{g}^{-1}(\mathrm{PAC}) \text { and } 7.936 \mathrm{mg} \cdot \mathrm{g}^{-1} \\
(\mathrm{AE})\end{array}$ & [11] \\
\hline
\end{tabular}

The dyes adsorption was carried out employing two methodologies: in-situ (IS) adsorption, where MB and RB5 are added to the HKUST-1 synthesis, and post-synthesis (PS) retention. In order to determine the physicochemical properties of the synthesized MOF we report DRX, IR, TGA and nitrogen adsorption characterization. UV-Vis spectroscopy was employed to quantify the amount of dyes adsorbed.

\section{EXPERIMENTAL PROCEDURE}

\section{A. Reagents and Materials}

Benzene-1,3,5-tricarboxylic acid (BTC, 95\% purity), copper nitrate $(99.99 \%$ grade $)$ methylene blue (3,7-bis(Dimethylamino)phenazathionium chloride, Basic Blue 9, Tetramethylthionine chloride) and reactive black 5 (Remazol Black B, >50\%) were acquired from Sigma-Aldrich. Ethanol anhydrous (99\% of purity, Aldrich) and deionized water were used as solvents. All the chemicals were used as received.

\section{B. Synthesis Procedure}

In-situ elimination. $2.0 \quad \mathrm{mmol}$ of benzene-1,3,5-tricarboxylic acid were dissolved in $100 \mathrm{~mL}$ of distilled water. $50 \mathrm{~mL}$ of dye solution (200 and $100 \mathrm{ppm}$ for $\mathrm{MB}$ and RB5, respectively) was added first solution. A second solution prepared with $3.0 \mathrm{mmol}$ of copper nitrate in $40 \mathrm{~mL}$ of ethanol anhydrous was gradually added to the previous solution. The mixture was stirred at room temperature for $12 \mathrm{~h}$. The resulting product was isolated by centrifugation and dried at $323 \mathrm{~K}$ for $2 \mathrm{~h}$. Solid and liquid obtained were stored for further characterization.

Post-synthesis elimination. HKUST-1 was prepared using the reported procedure by Loera-Serna et al. [31] The quantity of $2.38 \mathrm{mmol}$ of 1,3,5-benzenetricarboxylic acid was dissolved in $100 \mathrm{~mL}$ of distilled water. Then, a solution containing the quantity of $3.57 \mathrm{mmol}$ of copper nitrate trihydrate and $40 \mathrm{~mL}$ of ethanol was added drop by drop. The synthetic mixture was stirring at room temperature during 12 h. The resulting HKUST-1 product was isolated by centrifugation and dried at $323 \mathrm{~K}$ for $2 \mathrm{~h}$. Before adsorption, the HKUST-1 was dried overnight at $373 \mathrm{~K}$ and $10^{-3}$ Torr. The ratio of adsorbent/dye was $0.5 \mathrm{~g} / 50 \mathrm{~mL}$ (200 and 100 ppm for MB and RB5, respectively).

\section{Characterization}

\section{1) Powder X-ray diffraction}

The MOFs were characterized by X-ray diffraction (XRD) analysis. A powder diffractometer (Philips X'PERT PRO) coupled to a copper anode X-ray tube was used for the identification of compounds present in each sample. The Ka1 radiation $(45 \mathrm{kV}, 40 \mathrm{~mA}, \mathrm{k}=1.5406 \AA$ ) was selected with a diffracted beam monochromator and with a step size of 0.01 " and a time per step of $0.9 \mathrm{~s}$.

\section{2) Fourier transform infrared spectroscopy}

The FT-IR spectra (4000-650 $\mathrm{cm}^{-1}$ ) were obtained with a $2 \mathrm{~cm}^{-1}$ resolution at room temperature on a Bruker Tensor-27 spectrometer, fitted with a DTGS detector. The samples were previously prepared as $\mathrm{KBr}$ mixtures and recorded via the ATR technique.

\section{3) Thermogravimetric analyses}

The experiments were preformed under $\mathrm{N}_{2}$ atmosphere at a 
heating rate of $5{ }^{\circ} \mathrm{C} / \mathrm{min}$ with a TA TGA Q500 (TA Instruments, USA). The samples were heated from room temperature to $500{ }^{\circ} \mathrm{C}$.

\section{4) Nitrogen adsorption}

All adsorption measurements were conducted using a BELSORP-max (BELL Japan Inc.) system at $-196{ }^{\circ} \mathrm{C}$. Samples were degassed under dynamic conditions (extra-dry air flow) over $24 \mathrm{~h}$ at $100{ }^{\circ} \mathrm{C}$ prior to adsorption measurements. BET specific surface areas were calculated from the $\mathrm{N}_{2}$ adsorption isotherms.

\section{5) Ultraviolet-visible spectroscopy}

Spectrophotometric analysis was performed using a Shimadzu Pharm Spec UV-VIS spectrometer.

\section{RESUlTS AND DISCUSSION}

\section{A. The HKUST-1 Sample}

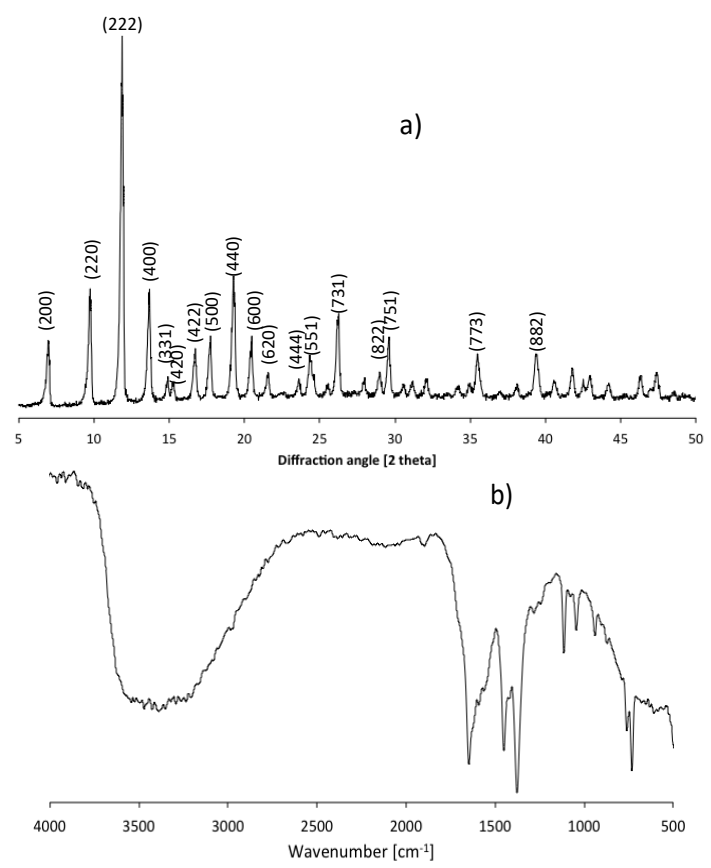

Fig. 2. a) XRD and b) FTIR of HKUST-1 sample.

Diffraction peaks in Fig. $2 \mathrm{a}$ are readily indexed as the cubic structure of the copper metal organic framework, known as HKUST-1 or $\mathrm{Cu}_{3}(\mathrm{BTC})_{2}$ [29]. The cell parameter is $26.11 \AA$ and the crystal size of $115 \mathrm{~nm}$. The FTIR spectrum of HKUST-1 (Fig. 2b) evidenced an almost isobidentate behavior of the -COO moiety since bands at 1645, 1620, $1570,1550,1450$ and $1378 \mathrm{~cm}^{-1}$ are characteristic of this coordination mode. The latter due to the fact that iso- and aniso-bidentate dicopper (II) carboxylate, type of monomeric clusters are present within the HKUST-1 frame. Additionally, the thermal stability of HKUST-1 was determined by TGA, finding the structure is decomposed at $337^{\circ} \mathrm{C}$. The HKUST-1 sample exhibited a continuous mass loss of $20.1 \%$, up to a temperature of $100{ }^{\circ} \mathrm{C}$ due to the loss of ethanol and water. After decomposition, at $336.9{ }^{\circ} \mathrm{C}, 23.5 \%$ of the starting weight remains, and this residual material could correspond to the formation of copper oxides, metallic copper or residual carbon [32]. The HKUST-1 synthesized by stirring at room temperature generates a 3D structure with BET and Langmuir specific surface area of 1345.9 and $1637.6 \mathrm{~m}^{2} \mathrm{~g}^{-1}$, respectively. Such values indicate a considerably a high area for this type of MOF [31].

Fig. 3 shows the SEM micrographs of HKUST-1. The HKUST-1 particles have a well defined octahedral shape, with a homogenous particle size $(2-4 \mu \mathrm{m})$. This morphology is characteristic of the HKUST-1 structure [33], but rarely is observed with the present synthesis conditions: stirring at room temperature.

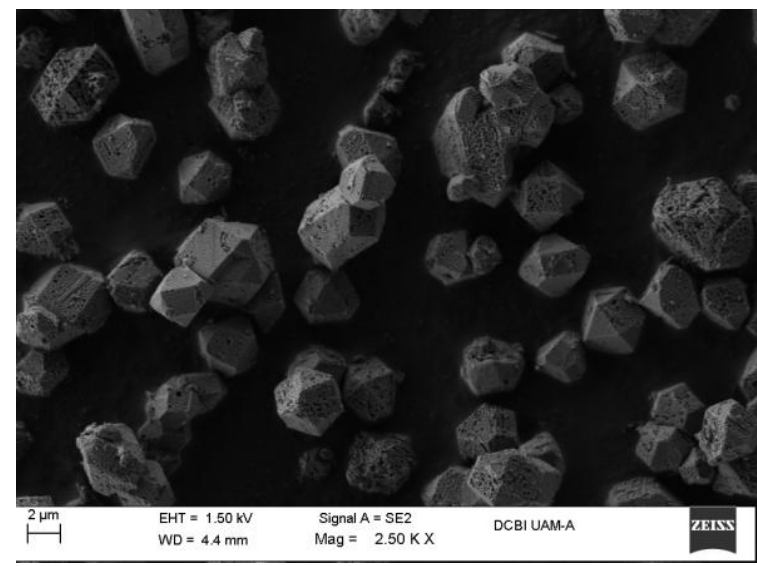

Fig. 3. SEM micrograph of HKUST-1.

\section{B. MB Eliminated by Adsorption on HKUST-1}
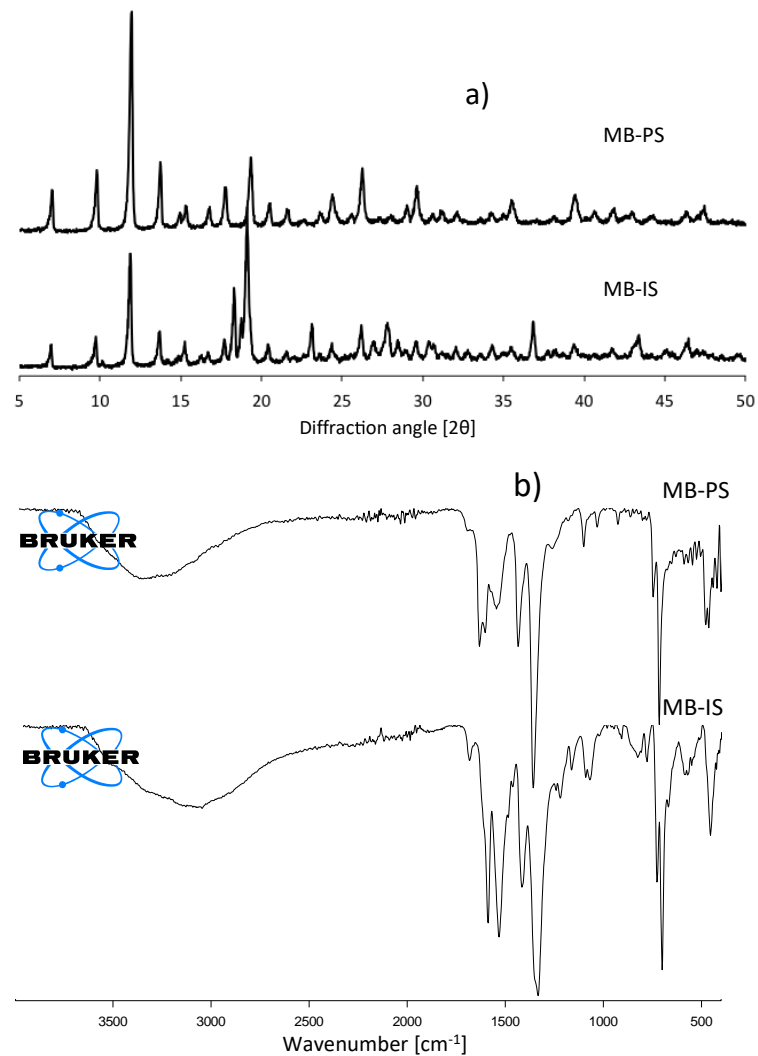

Fig. 4. a) XRD and b) FTIR of MB adsorbed in HKUST-1.

Fig. 4a) presents the X-ray diffraction pattern of MB-IS and MB-PS. The diffraction peaks in both diffractograms correspond to the HKUST-1 structure. New peaks at $2 \theta$ of 18.3 and 36.8 appear in sample MB-IS, corresponding to an unidentified new crystalline compound, not present in the 
HKUST-1 pattern.

When MB was incorporated onto the HKUST - 1 structure by the IS procedure, the cell parameter was $26.75 \mathrm{~A}$, bigger than cell parameter of pure HKUST $-1(26.11 \AA)$, for the MB-PS the cell parameter was $26.67 \AA$. MB molecules can generate interactions inside the HKUST-1 cavities, responsible for increasing of cell parameter; these dye molecules can replace the solvent molecules inside the MOF structure. The crystal size determined by the Scherrer equation [34] was 64 and $97 \mathrm{~nm}$ for, MB-IS and MB-PS, respectively.

Fig. $4 \mathrm{~b}$ compares the FTIR spectra of MB-IS and MB-PS. All main bands correspond to functional groups in the HKUST-1 structure. Additional bands at 1598.67, 1422.34 and $1364.67 \mathrm{~cm}^{-1}$, belong to the functional groups present in the MB molecule, according to the Spectra Data Base of Organic Compounds (SDBS).

Table II compares the surface area of the pure HKUST-1 with those belonging to samples containing MB and RB5; as expected, in all samples the surface area decreased when the dye molecules were adsorbed on the MOF structure.

TABLE II: BET AND LANGMUIR SPECIFIC SURFACE AREA OF SYNTHESIZED

\begin{tabular}{lll}
\multicolumn{3}{c}{ SAMPLES } \\
\hline \hline Sample & $\mathrm{A}_{\text {BET }}\left(\mathrm{m}^{2} \mathrm{~g}^{-1}\right)$ & $\mathrm{A}_{\text {Langmuir }}\left(\mathrm{m}^{2} \mathrm{~g}^{-1}\right)$ \\
\hline HKUST-1 & 1345.9 & 1637.6 \\
MB-IS & 945.7 & 1127.6 \\
MB-PS & 664.8 & 825.4 \\
RB5-IS & 773.5 & 903.2 \\
RB5-PS & 710.5 & 854.3 \\
\hline \hline
\end{tabular}

The micrographs obtained by SEM, of MB-IS and MB-PS materials are presented in Fig. 5. The morphological form of MB-IS samples is the same as HKUST-1, a well defined octahedral $(2 \mu \mathrm{m})$. However, MB-IS particles present small pores on the surface. On the other hand, MB-PS exhibit agglomerated particles with a truncated octahedral shape of about $10 \mu \mathrm{m}$ particle size.

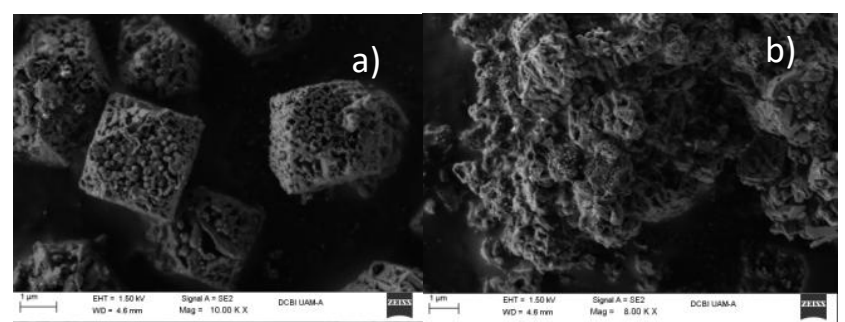

Fig. 5. SEM micrographs of a) MB-IS and MB-PS.

\section{RB5 Eliminated by Adsorption on HKUST-1}

Powder X-ray diffraction patterns of samples containing RB5 are compared in Fig. 6a. The diffraction peaks in all diffractograms, correspond to the HKUST-1 structure; no additional peaks are present, in an indication that the incorporation of the dye do not modify the structure of HKUST-1 or that the concentration of the dye is small enough for not being detected. The main difference after the adsorption procedure is the relative intensity of some diffraction peaks attributed to the presence of dyes molecules in some crystallographic planes. When RB5 was incorporated into the HKUST-1 structure by in -situ adsorption (RB5-IS) the resultant cell parameter was 26.11
$\AA$, whereas RB 5 was incorporated by post -synthesis methodology (RB5-PS) and the cell parameter was $26.17 \AA$. The difference, ca. $1 \%$, is relevant and beyond experimental error. The crystal size determined by the Scherrer equation [34] was 63 and $43 \mathrm{~nm}$ for RB5-IS and RB5-PS respectively.

Fig. 6b) compares the FTIR spectra of RB5-IS and RB5-PS. All bands belonging to HKUST-1 are present in both spectra. Additional bands at 1446.31, 1370.95 and $596.41 \mathrm{~cm}^{-1}$, corresponding to the azo and sulfonate groups, are present in the RB5 sample, according to the SDBS Data Base.

The thermal stability of RB5-IS and RB5-PS was determined by TGA. Both samples show a continuous mass loss of $15.6 \%$ and $14.8 \%$, respectively, up to a temperature of $100{ }^{\circ} \mathrm{C}$ due to the loss of ethanol and water. The thermal degradation of RB5-IS and RB5-PS occurred at 333.9 and $340.6^{\circ} \mathrm{C}$, respectively. The residual material after the thermal decomposition of HKUST-1 was 25.45 and $29.5 \%$ for RB5-IS and RB5-PS, respectively. These results are higher than the percentage of material remaining in the TGA of the pure HKUST-1 $(23.5 \%)$, due to the presence of the dyes molecules.

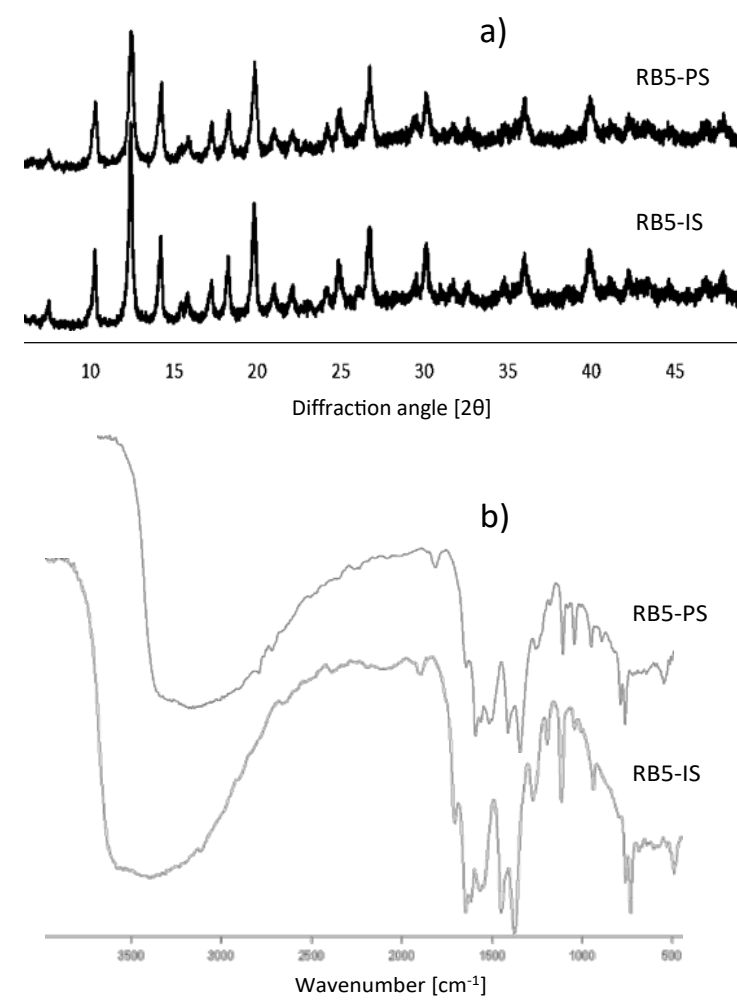

Fig. 6. a) XRD and b) FTIR of RB5 adsorbed in HKUST-1.

The BET and Langmuir specific surface area of RB5-IS and RB5-PS determined by nitrogen adsorption are presented in Table II. As mentioned before, the HKUST-1 surface area decreases because MB molecules can incorporate inside the pores and replace the solvent molecules. On the other hand, RB5 molecules are bigger than MB molecules, and can not access the HKUST -1 pores $(9.5$ or $13.3 \AA$ size across its diagonal); these molecules interact on the surface structure via Van der Waals interactions.

SEM micrographs of RB5-IS and RB5-PS are compared in Fig. 7. Sample RB5-IS presents a well-defined octahedral shape, as the pure HKUST-1, but with small pores on the 
surface. The particle size are in the same order as the pure HKUST-1, between 2 and $4 \mu \mathrm{m}$. On the other hand, RB5-PS exhibit agglomerated particles with a truncated octahedral shape of about $6 \mu \mathrm{m}$ particle size and some smaller particles of around 1-2.5 $\mu \mathrm{m}$ (Fig. 7b).

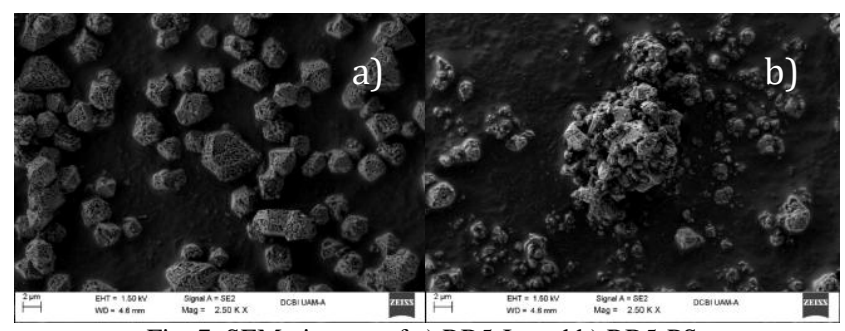

Fig. 7. SEM pictures of a) RB5-Is and b) RB5-PS.

\section{Quantification of $M B$ and RB5}

The liquids from the filtrate from HKUST-1 and the MB and RB5 solutions were analyzed with UV-Vis spectroscopy. Calibration curves and the quantification of the dyes molecules were carried out using the Beer-Lambert Law; the concentration of the not adsorbed MB and RB5 was also determined (Table III).

TABLE III: PERCENTAGES OF MB AND RB5 RETAINED IN HKUST-1, DETERMINED BY VU-VIS

\begin{tabular}{llll}
\hline \multicolumn{4}{c}{ DETERMINED BY VU-VIS } \\
\hline MB-IS & \% of MB & Sample & \% RB5 \\
MB-PS & 58.11 & RB5-IS & 82.68 \\
& 93.57 & RB5-PS & 75.01
\end{tabular}

\section{CONCLUSIONS}

The preparation method discussed in this work provides a HKUST-1 MOF with crystalline cubic structure and high surface area. The thermal stability of the material is above $300{ }^{\circ} \mathrm{C}$. Adsorption of two organic molecules, extensively used as textile dyes was conducted by two different strategies; the first adsorption strategy was during the synthesis of the HKUST-1 (is-situ adsorption) and the second one during the post-synthesis process. $58.11 \%$ of methylene blue, MB, was retained by the MOF by in-situ adsorption and $93.57 \%$ by post-synthesis adsorption. Therefore a large proportion of the dye was effectively eliminated from the water effluent when employing the PS method because the dye molecules are able to get inside the MOF's pore suystem. $82.68 \%$ of reactive black 5, RB5, was retained by the MOF by in-situ adsorption and $75.01 \%$ by post-synthesis adsorption. Compared to MB, a smaller amount of RB5 was retained by the MOF by the PS method, due to the larger size of the RB5 molecule that makes it more difficult to fit inside the MOF's pore system; nevertheless, the retention of RB5 achieved by the IS method, makes this procedure an attractive alternative for dye removal water treatment. Therefore, the adsorption of dyes on the HKUST-1 MOF depends on the chemical and physicochemical characteristics of the adsorptive molecule, such as the functional groups or the molecule size. A considerable percentage of molecules with even bigger size than the HKUST-1 pore size, can be adsorbed on the external surface framework.

\section{ACKNOWLEDGMENT}

We acknowledge Fernando Almanza-Hernández for his help with the SEM analysis. We recognize the kind revision and amendments to this contribution done by all the reviewers as well as some of our colleagues. The authors would like to thank Veronica Rosales-Hernandez and Ana Karina Hernández-Rangel, for their practical assistance in starting up the experiments.

\section{REFERENCES}

[1] N. Board, The Complete Technology Book on Dyes \& Dye Intermediates, National Institute of Industrial RE, 2003.

[2] A. Al-Kdasi, A. Idris, K. Saed, and C. T. Guan, "Treatment of textile wastewater by advanced oxidation processes - A review," Global Nest: The Int. J, vol. 6, pp. 222-230, 2004.

[3] I. Oller, S. Malato, and J. Sánchez-Pérez, "Combination of advanced oxidation processes and biological treatments for wastewater decontamination - A review," Science of the Total Environment, vol. 409, pp. 4141-4166, 2011.

[4] J. L. Rowsell and O. M. Yaghi, "Metal-organic frameworks: a new class of porous materials," Microporous and Mesoporous Materials, vol. 73, pp. 3-14, 2004.

[5] E. C. Childs and N. Collis-George, "The permeability of porous materials," in Proc. the Royal Society of London A: Mathematical, Physical and Engineering Sciences, The Royal Society, 1950, pp. 392-405.

[6] J. Rouquerol, F. Rouquerol, P. Llewellyn, G. Maurin, and K. S. Sing, Adsorption by Powders and Porous Solids: Principles, Methodology and Applications, Academic press, 2013.

[7] S. W. Puasa, M. S. Ruzitah, and A. S. A. K. Sharifah, "Competitive removal of reactive black 5/reactive orange 16 from aqueous solution via micellar-enhanced ultrafiltration," International Journal of Chemical Engineering and Applications, pp. 354-358, 2012.

[8] D. Cross, "A review of methods to control ichthyophthiriasis," The Progressive Fish-Culturist, vol. 34, pp. 165-170, 1972.

[9] S. Thevarajah, T. L. Huston, and R. M. Simmons. "A comparison of the adverse reactions associated with isosulfan blue versus methylene blue dye in sentinel lymph node biopsy for breast cancer," The American Journal of Surgery, vol. 189, pp. 236-239, 2005.

[10] I. Poulios and I. Tsachpinis, "Photodegradation of the textile dye Reactive Black 5 in the presence of semiconducting oxides," Journal of Chemical Technology and Biotechnology, vol. 74, pp. 349-357, 1999.

[11] Z. Eren and F. N. Acar, "Adsorption of reactive black 5 from an aqueous solution: Equilibrium and kinetic studies," Desalination, vol. 194, pp. 1-10, 2006.

[12] S. Lin, Z. Song, G. Che, A. Ren, P. Li, C. Liu, and J. Zhang, "Adsorption behavior of metal-organic frameworks for methylene blue from aqueous solution," Microporous and Mesoporous Materials, vol. 193, pp. 27-34, 2014.

[13] E. Haque, J. W. Jun, and S. H. Jhung, "Adsorptive removal of methyl orange and methylene blue from aqueous solution with a metal-organic framework material, iron terephthalate (MOF-235)," J Hazard Mater, vol. 185, pp. 507-511, 2011.

[14] M. S. Tehrani and R. Zare-Dorabei, "Highly efficient simultaneous ultrasonic-assisted adsorption of methylene blue and rhodamine B onto metal organic framework MIL-68(Al): Central composite design optimization," RSC Adv., vol. 6, pp. 27416-27425, 2016.

[15] H. Deng, J. Lu, G. Li, G. Zhang, and X. Wang, "Adsorption of methylene blue on adsorbent materials produced from cotton stalk," Chemical Engineering Journal, vol. 172, pp. 326-334, 2011.

[16] M. Dogan, H. Abak, and M. Alkan, "Adsorption of methylene blue onto hazelnut shell: Kinetics, mechanism and activation parameters," $J$ Hazard Mater, vol. 164, pp. 172-181, 2009.

[17] G. L. Dotto, J. M. Santos, I. L. Rodrigues, R. Rosa, F. A. Pavan, and E. C. Lima, "Adsorption of Methylene Blue by ultrasonic surface modified chitin," J Colloid Interface Sci, vol. 446, pp. 133-140, 2015.

[18] B. H. Hameed and A. A. Ahmad, "Batch adsorption of methylene blue from aqueous solution by garlic peel, an agricultural waste biomass," $J$ Hazard Mater, vol. 164, pp. 870-875, 2009.

[19] B. H. Hameed, A. T. Din, and A. L. Ahmad, "Adsorption of methylene blue onto bamboo-based activated carbon: kinetics and equilibrium studies," J Hazard Mater, vol. 141, pp. 819-825, 2007.

[20] T. Liu, Y. Li, Q. Du, J. Sun, Y. Jiao, G. Yang, Z. Wang, Y. Xia, W. Zhang, K. Wang, H. Zhu, and D. Wu, "Adsorption of methylene blue 
from aqueous solution by graphene," Colloids Surf B Biointerfaces, vol. 90, pp. 197-203, 2012.

[21] M. Rafatullah, O. Sulaiman, R. Hashim, and A. Ahmad, "Adsorption of methylene blue on low-cost adsorbents: A review," J Hazard Mater, vol. 177, pp. 70-80, 2010.

[22] X. Zhang, P. Zhang, Z. Wu, L. Zhang, G. Zeng, and C. Zhou, "Adsorption of methylene blue onto humic acid-coated $\mathrm{Fe} 3 \mathrm{O} 4$ nanoparticles," Colloids and Surfaces A: Physicochemical and Engineering Aspects, vol. 435, pp. 85-90, 2013.

[23] P. Horcajada, T. Chalati, C. Serre, B. Gillet, C. Sebrie, T. Baati, J. F. Eubank, D. Heurtaux, P. Clayette, and C. Kreuz, "Porous metal-organic-framework nanoscale carriers as a potential platform for drug delivery and imaging," Nature Materials, vol. 9, pp. 172-178, 2010.

[24] S. Loera-Serna and E. Ortiz, "Catalytic applications of metal-organic frameworks," 2016.

[25] P. L. Llewellyn, G. Maurin, T. Devic, S. Loera-Serna, N. Rosenbach, C. Serre, S. Bourrelly, P. Horcajada, Y. Filinchuk, and G. Férey, "Prediction of the conditions for breathing of metal organic framework materials using a combination of X-ray powder diffraction, microcalorimetry, and molecular simulation," Journal of the American Chemical Society, vol. 130, pp. 12808-12814, 2008.

[26] T. K. Trung, P. Trens, N. Tanchoux, S. Bourrelly, P. L. Llewellyn, S. Loera-Serna, C. Serre, T. Loiseau, F. Fajula, and G. Férey, "Hydrocarbon adsorption in the flexible metal organic frameworks MIL-53 (Al, Cr)," Journal of the American Chemical Society, vol. 130, pp. 16926-16932, 2008.

[27] O. Shekhah, J. Liu, R. Fischer, and C. Wöll, "MOF thin films: existing and future applications," Chemical Society Reviews, vol. 40, pp 1081-1106, 2011

[28] D. Farrusseng, Metal-Organic Frameworks: Applications from Catalysis to Gas Storage, John Wiley \& Sons, 2011.

[29] S. S.-Y. Chui, S. M.-F. Lo, J. P. Charmant, A. G. Orpen, and I. D. Williams, "A chemically functionalizable nanoporous material $[\mathrm{Cu} 3$ (TMA) 2 (H2O) 3] n," Science, vol. 283, pp. 1148-1150, 1999.

[30] S. Loera-Serna, M. A. Oliver-Tolentino, M. L. López-Núñez, A. Santana-Cruz, A. Guzmán-Vargas, R. Cabrera-Sierra, H. I. Beltrán, and J. Flores, "Electrochemical behavior of [Cu 3 (BTC) 2] metal-organic framework: The effect of the method of synthesis," Journal of Alloys and Compounds, vol. 540, pp. 113-120, 2012.

[31] S. Loera-Serna, L. L. Núñez, J. Flores, R. López-Simeon, and H. I. Beltrán, "An alkaline one-pot metathesis reaction to give a [Cu 3 (BTC) 2] $\mathrm{MOF}$ at rt, with free $\mathrm{Cu}$ coordination sites and enhanced hydrogen uptake properties," RSC Advances, vol. 3, pp. 10962-10972, 2013.

[32] E. Biemmi, S. Christian, N. Stock, and T. Bein, "High-throughput screening of synthesis parameters in the formation of the metal-organic frameworks MOF-5 and HKUST-1," Microporous and Mesoporous Materials, vol. 117, pp. 111-117, 2009.

[33] F. Wang, H. Guo, Y. Chai, Y. Li, and C. Liu, "The controlled regulation of morphology and size of HKUST-1 by "coordination modulation method," Microporous and Mesoporous Materials, vol. 173, pp. $181-188,2013$

[34] J. I. Langford and A. Wilson, "Scherrer after sixty years: a survey and some new results in the determination of crystallite size," Journal of Applied Crystallography, vol. 11, pp. 102-113, 1978.

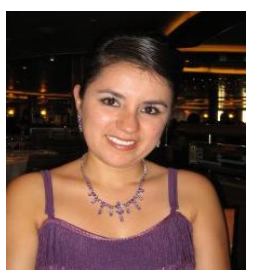

S. Loera-Serna was born in Mexico City on September 26, 1982. In 2005 she obtained her first degree in chemistry (2005) from the Metropolitan Autonomous University Iztapalapa, UAM-Iztapalapa, and her MSc (2007) and PhD (2010) degrees from the National Autonomous University of Mexico (Thesis with honors). She is senior professor at the Department of Basic Science of the Metropolitan Autonomous University Azcapotzalco, Mexico. She published 17 papers in international journals. She is a member of Mexico's National System of Researches (SNI). Her areas of research interest include design of new porous materials, adsorption, wastewater treatments and treatment of textile dyes.

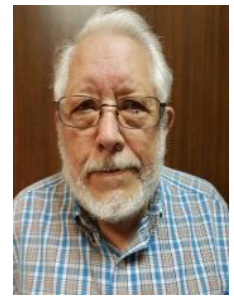

H. Solis was born in Mérida, Yucatan, Mexico on June 26,1945 . He is lecturer at the UAM-Azcapotzalco, Mexico, since 1974. He obtained her first degree in chemistry engineering (1971) from the School of Chemistry, Yucatan University. Ms. Sc. inorganic chemistry, Universidad de Guanajuato, Guanajuato, Mexico, 1975. Ph. D. sciences and engineering, environmental, Metropolitan Autonomous University, UAM-Azcapotzalco, México, 2012. Among his most outstanding works are: Nomenclatura Quimica. Hugo Solís-Correa. Editorial Patria, México. 2009. 173 pages. Chemical degradation of indigo potassium tetrasulfonate dye by advanced oxidation processes. V. Camargo, E. Ortiz, H Solís-Correa, C. Cortés-Romero, S. Loera, C. Pérez. Journal of Environmental Protection, 2014, 5, 1342-1351. Indigo Stability: an ab initio study. H. Solis-Correa, E. Ortiz, I. Barceló, J. L. Hernández-Ávila., Molecular Simulation, 2011, 37(13), 1085-1090. He is a Teaching, in Chemical degradation of pollutants in aqueous medium.

Dr. Solis received the Teaching Award 1995 by the UAM- Azcapotzalco, México. Dean of Department of Basic Sciences 1999-2003 by UMA-Azcapotzalco, México.

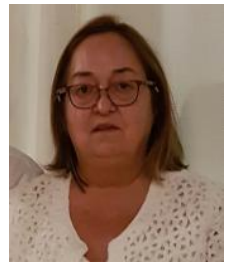

E. Ortiz got the $\mathrm{PhD}$ in chemistry teaching experience in Mexican Universities in the areas of quantum chemistry, physical chemistry, air pollution, atmospheric chemistry and environmental protection. She has tutored forty doctoral thesis, master's and bachelor's degrees. She is now recognized as a member of the National Research System level II. She has published thirty scientific papers for refereed journals internationally. Author of five books and twenty chapters of books on aerosols, emission inventory, modeling ozone, air quality in urban areas, environmental impact of fuels specialist research in the description of chemical reactivity, using mathematical models. Extensive experience in the areas of air pollution gases and airborne, atmospheric chemistry, ozone, aerosols, nuclear techniques in environmental monitoring, personal monitoring, environmental and environmental micro toxic, photochemical reactivity.

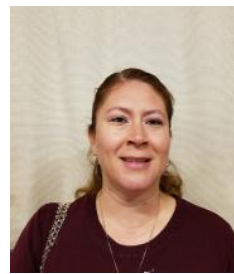

A. L. Martínez-Hernánez received her PhD in 2003 at Universidad Autonoma de Querétaro for work on keratin biofibers characterization, studying their applications as novel microstructural material obtained from poultry industry residues. Her research was developed at CFATA-UNAM. She was in a postdoctoral stay at LAPOM in University of North Texas, in Denton. Actually she is member of Graduate Studies and Research Division at Instituto Tecnologico de Querétaro, where she is head of the Advanced Materials and Nanotechnology Research Group.

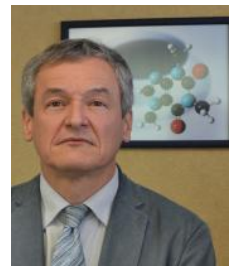

L. Noreña occupies the position of senior professor at the Department of Basic Science of the Metropolitan Autonomous University, UAM-Azcapotzalco, Mexico. He obtained her first degree in Chemical Engineering (1989) from the National Autonomous University of Mexico, and his MSc. 1993) and PhD (1997) degrees from the University of Manchester Institute of Science and Technology, England. From November 2007 to October 2011, he was the Head of the Department of Basic Sciences, and from May 2012 to April 2016, he was the Director of the Division of Basic Sciences and Engineering. He is a member of Mexico's National System of Researches (SNI). His current research interest includes the synthesis, characterization, and applications of porous catalytic materials and applications of polymers with electrical properties. 